\title{
Effects of ownership structure and corporate and family governance on dynamic capabilities in family firms
}

\section{César Camisón-Zornoza ${ }^{1}$ • Beatriz Forés-Julián ${ }^{2}$ • Alba Puig-Denia ${ }^{2}$. Sergio Camisón-Haba ${ }^{1}$}

Published online: 28 May 2020

(C) Springer Science+Business Media, LLC, part of Springer Nature 2020

\begin{abstract}
By combining the resource-and capabilities-based view and agency theory, this paper offers a framework within which to examine the nature of dynamic capabilities in family firms, and how they are affected by the ownership, governance and management structures. We focus on technology-based innovation capabilities, differentiating between sensing, seizing and transforming capabilities. We expand the analysis of family involvement, defined as the family firm owner's ability to influence firm behavior, identifying three distinct structures that underpin decision-making power and control capacity in family firms: the capital structure, the governance and management structure of the business; and the governance structure of the family itself. The empirical
\end{abstract}

\footnotetext{
Highlights

The effects of capital structure and the business and family governance structures on the dynamic capabilities are asymmetric and opposite.

A concentrated ownership structure shows a negative effect.

High familiar control of capital, which represents an important quota of family wealth, shows a negative effect. High family involvement in top management team shows a negative effect.

An effectively functioning family council and the implementation of family management instruments show, on the other hand, a positive effect.
}

Sergio Camisón-Haba

sergio.camison@uv.es

César Camisón-Zornoza

cesar.camison@uv.es

Beatriz Forés-Julián

bfores@uji.es

Alba Puig-Denia

puiga@emp.uji.es

1 Universitat de València, Av. de Blasco Ibáñez, 13, 46010 València, Spain

2 Universitat Jaume I Castelló, Avinguda de Vicent Sos Baynat, s/n, 12071 de la Plana, Castelló, Spain 
research was carried out on a sample of 748 family firms from the Spanish tourism industry. We find that the effects of these dimensions of family involvement on dynamic capabilities are asymmetric. A concentrated ownership structure with a high degree of family control and a substantial share of family wealth committed to the business are shown to have a negative effect. The management structure is shown to be the key body for fostering the accumulation of dynamic capabilities, although a high level of family involvement in the top management team and having a family member as CEO represent major barriers to this process. On the other hand, the board of directors and its composition appear not to be relevant structural elements. The most powerful structural factor in facilitating the development of innovation capabilities is the existence of an effective family board and the implementation of family management instruments. These mechanisms help to mitigate the negative effects of a familycontrolled ownership and management structure. The findings represent a significant contribution to the literature on family firms, innovation management and corporate governance.

Keywords Family firm · Governance · Ownership structure · Dynamic capabilities

\section{Introduction}

In the family firm (FF) literature, growing attention is being paid to innovation (Craig and Moores 2006; Block 2012; Chirico and Salvato 2008; De Massis et al. 2012; De Massis et al. 2013; De Massis et al. 2015; Matzler et al. 2015; Duran et al. 2016; Cucculelli et al. 2016; Decker and Günther 2017), as it is a key factor in firms' continual adaptation to a changing environment (Sirmon et al. 2007) and effective corporate entrepreneurship (Zahra et al. 2006). Nevertheless, this increasing academic focus has yet to yield conclusive results, suggesting that the relationship between FF and innovation is more complex than initially assumed (Miller et al. 2008; Fuetsch and Suess-Reyes 2017). One reason why the question is not yet settled is that the difference between implemented innovation or innovation performance and dynamic or innovation capabilities has often been overlooked or misunderstood. Dynamic capabilities are key elements in ensuring superior and sustained innovation and long-term competitiveness (Brown and Eisenhardt 1995; Teece et al. 1997; Teece 2007; Eisenhardt and Martin 2000). Despite the natural logic of this relationship, research on the differential FF characteristics that may facilitate or hinder the creation and development of dynamic capabilities is still in an embryonic phase (Chirico and Salvato 2008; De Massis et al. 2013; De Massis et al. 2016). In fact, almost all of the published studies are limited to a theoretical perspective (Chirico and Salvato 2008), or exploratory case studies (Salvato and Melin 2008; Chirico and Nordqvist 2010; Fitz-Koch and Nordqvist 2017). The objective of this research is to provide a robust empirical analysis of the effect of ownership, management and corporate and family governance structures on the development of dynamic capabilities in the FF.

The identity and diversity of the owning group and the way in which it exercises its power in the FF are reflected in the firm's strategy, structure, culture and results (Judge 2012; Cruz and Nordqvist 2012; Sciascia et al. 2014). The specific ownership, control and management structures of FFs generate certain preferences in financing (Gallo et al. 
2004) and in investment and resource contracting policies (Gedajlovic and Carney 2010; Duran et al. 2016). They also shape decision-making mechanisms (CabreraSuárez et al. 2001), the system of economic and non-economic objectives (Kammerlander and Ganter 2015) oriented towards the family and the business (Kotlar and De Massis 2013), socioemotional wealth (Hauck and Prügl 2015), the organizational culture (Chrisman et al. 2015), entrepreneurial attitude (Nordqvist and Melin 2010; Randerson et al. 2015) and the human system (Carnes and Ireland 2013), which particularly affect change acceptance and risk aversion (Zahra 2005). However, the background analysis of dynamic capabilities has been limited to a theoretical focus on some of the characteristics associated with family ownership and control, such as a long-term orientation (Miller and Le Breton-Miller 2006; Zahra et al. 2006) or the intergenerational transmission of organizational culture (Chirico and Nordqvist 2010). The few studies that include empirical analysis have chosen to restrict the determinants to an index of overall family involvement (Zahra et al. 2007; Lichtenthaler and Muethel 2012). The first contribution that this research makes to the FF literature is that it is the first study, to the best of our knowledge, to take a quantitative statistical approach to analysing the impact of ownership, management and governance (corporate and family) structures on dynamic capabilities. The added value of the research lies in pinpointing and clearly defining three distinct structures underpinning the decisionmaking power and control capacity in FFs: the capital structure, the management and governance structure of the business; and the governance structure of the family itself. The degree of family involvement in each of these structures is different, and their effects on the development of dynamic capabilities are asymmetric.

Secondly, the study contributes to innovation management research by robustly identifying the structural factors that bolster the innovation capacity of the FF, and those that inhibit it. In terms of FF research, these structural governance mechanisms have major implications to consider; as such, numerous authors have turned their attention to the analysis of these factors (e.g., Nordqvist et al. 2014; Villalonga et al. 2015). However, there are almost no studies that focus on the potential for these mechanisms to develop dynamic capabilities. Our results have interesting practical implications, so this paper responds to the call by some papers in the literature on innovation and FF (Drazin and Schoonhoven 1996; Fuetsch and Suess-Reyes 2017) to avoid ivory tower visions.

A third contribution is the empirical evidence showing that the design of and family involvement in the board of directors does not play an important role in the development of dynamic capabilities. This conclusion contradicts certain topics often highlighted in both the literature (e.g., Jensen and Meckling 1976; Fama and Jensen 1983) and in corporate governance practice, which attribute a major role to the board in shaping the firm's behaviour. In contrast, our study identifies the business management and family governance structures as the principal determinants of innovation capacity in FFs.

The tourism industry provides the ideal context for examining the relationships between ownership structure, and corporate and family governance models on the one hand, and the development of dynamic capabilities in FF on the other. There are two reasons for this. First, tourism firms display a wide diversity of ownership structures, including entrepreneurs, families, institutional investors and financial companies. This variation in ownership structures is accompanied by a similar diversity of management 
structures, ranging from independent establishments to large chains, and including participation in voluntary networks and exploitation agreements. As is to be expected, the variety of challenges posed by such heterogeneous management systems and ownership structures has given rise to varied corporate governance models. This heterogeneity makes it easier to study their comparative effects on the innovation capacities of FFs. Secondly, the tourism sector is a setting where radical, pioneering innovations in service delivery have emerged, not only due to the major penetration of new digital marketing solutions but also because of the opportunities offered by new business models.

The remainder of this paper is organized as follows. In Section 2, we explain the theoretical bases of our study; namely the resources and capabilities-based view (RCBV) and agency theory. In Section 3, we then develop our theoretical model to explain the roads leading to the accumulation of dynamic capabilities in privately-held, family-influenced businesses. After setting out the methodology for the empirical study in Section 4, we present and discuss the results from the empirical models in Section 5. The last section outlines the main conclusions of the research, along with the implications for management theory and practice, and indicates future research avenues.

\section{Theoretical framework}

Agency theory and the RCBV offer complementary perspectives from which to analyse the most relevant aspects of the effects of ownership, management and governance structures on decision-making in the firm, and therefore, on the development of capabilities. These theoretical approaches can thus provide an appropriate framework for analysing the implications of the design of such structures for dynamic capabilities and innovation.

RCBV stresses the key role played by firms' endowment of resources and capabilities in making them unique entities capable of achieving a sustainable competitive advantage over their competitors (Barney 1991; Amit and Schoemaker 1993; Peteraf 1993; Barney et al. 2001). In particular, the most dynamic line of research within the RCBV analyses how firms' resources are generated and combined to create new capabilities that can produce value over time through innovation (Teece et al. 1997; Eisenhardt and Martin 2000). This theoretical approach allows researchers to distinguish between innovation as an outcome, which is a measure of performance, and dynamic or innovation capabilities, which are sets of resources that management handles in a coordinated way in order to optimize innovation performance. Innovation as a product is, therefore, a visible result of the knowledge-generation capability and its application in the introduction of new or improved products or processes, or new organizational ideas (Un and Cuervo-Cazurra 2004). Dynamic capabilities are the basic source of sustainable competitive advantages and revenues. But the impact of dynamic capabilities on economic performance is first channelled through a more immediate outcome of these capabilities; namely, innovation performance (Bontis et al. 2002; Kellermanns et al. 2012).

Dynamic or innovation capabilities are precisely defined as the ability of an organization to integrate, renew, reconfigure and transform the external resources and complementary assets of the firm (Brown and Eisenhardt 1995; Teece et al. 1997; 
Eisenhardt \& Martín, 2000; Winter 2003; Zahra et al. 2006; Teece 2007). Dynamic capabilities are thus distinct from entrepreneurial orientation, understood as "processes, practices and decision-making activities that lead to new entry" (Lumpkin and Dess 1996: 136).

Dynamic capabilities are defined as higher-order integration capabilities (Lawson and Samson 2001) that encompass multiple abilities. Following Teece (2007), the routines and activities that support dynamic capabilities can be broken down into sensing, seizing and transforming capabilities. Sensing capabilities refer to identifying and generating new opportunities. Through innovation capabilities, organizations can adapt to changing circumstances in technology and the markets, and can even refresh or reinvent their business by expanding their stock of resources and capabilities with new knowledge. The firm's strategic flexibility therefore lies in its sensing capability, in other words, in its demonstrated ability to survey the environment and identify (Garg et al. 2003) or generate new opportunities by developing or internalizing new technologies that facilitate the launch of radically new products. Seizing capabilities consist of the ability to respond to the technological opportunities identified, by developing new products and processes (Heeley et al. 2007). In order for the new technologies detected to create value, they must be transferred to products and processes that meet market needs (Teece et al. 1997). Finally, transforming capabilities refers to how the company renews its innovation processes to remain competitive over time (Marsh and Stock 2006). This capability is essential in order for the firm to align these processes with technological and market changes, especially in dynamic environments (Zahra et al. 2006).

Since the development of resources and capabilities is the result of business decisions, the analysis of how they emerge requires a particular focus on the characteristic features of the responsible bodies that hold decision-making power. Agency theory has attempted to identify the design of the firm's ownership, management and governance structures that best ensure more effective decision-making in relation to preventing conflict, optimizing information management and exploiting opportunities (Williamson 1979; Fama and Jensen 1983, 1985). In this regard, this perspective has provided some recommended structural designs that help align ownership and management interests and objectives, and ensure that responsibility and decision-making power are in the best possible hands (Mayer and Schoorman 1992; Sundaramurthy and Lewis 2003). The most widely-used contractual instruments are professional management teams and boards of directors whose members are capable of fulfilling their supervisory and advisory functions (Jensen and Meckling 1976; Fama and Jensen 1983). As regards ownership structure, the agency theory literature has concluded that concentrated ownership is preferable as it helps prevent managers from behaving opportunistically. Such behaviour occurs when managers, faced with the accumulated power of the principal shareholders, and because their jobs depend on it, avoid taking decisions that run counter to the shareholders' interests (Fama and Jensen 1983). Our theoretical model thus includes three variables as determinants of dynamic capabilities: the existence of a management committee, the existence of a board of directors and concentration of capital.

Our definition of the concept of the FF is based on that suggested by Westhead and Cowling (1998) and Molly et al. (2010) but restricted to the dimension relating to family control of the share capital. Therefore, we consider a firm to be an FF when members of a particular family own more than $50 \%$ of the share capital. We have 
eliminated the other two criteria that those authors use in their definition: majority control of the board of directors by the owning family, and the participation of at least one family member in the management team. This is because they are, as noted above, explanatory variables that we include in our model.

These organizations are generally characterized by: (a) intergenerational family control of share capital (Miller and Le Breton-Miller 2005) and a substantial portion of the family's wealth committed to the business; (b) a high degree of involvement in the management and corporate governance structures, and even the position of CEO (Schulze et al. 2001), by family members with potentially divergent objectives and preferences (Gómez-Mejía et al. 2007, 2010) and with differing managerial capabilities (Habbershon and Williams 1999); and (c) the added complexity of the governance structures of the owning family itself (Nordqvist et al. 2014; Villalonga et al. 2015). These unique characteristics influence the processes of accumulating and renewing resources and capabilities (Chrisman et al. 2005), thereby shaping the firm's strategic behaviour (e.g., Astrachan et al. 2002; Le Breton-Miller and Miller 2006; Miller et al. 2007; Chrisman et al. 2012). We have therefore included these characteristics as determinants of dynamic capabilities in our theoretical model. Figure 1 depicts the set of variables suggested by the underlying theories proposed here to explain the innovation capabilities of FF.

\section{Hypotheses}

\section{Ownership structure and dynamic capabilities}

Agency theory points to the ownership structure as a determining factor of firm behaviour, since the ownership profile has important consequences in terms of

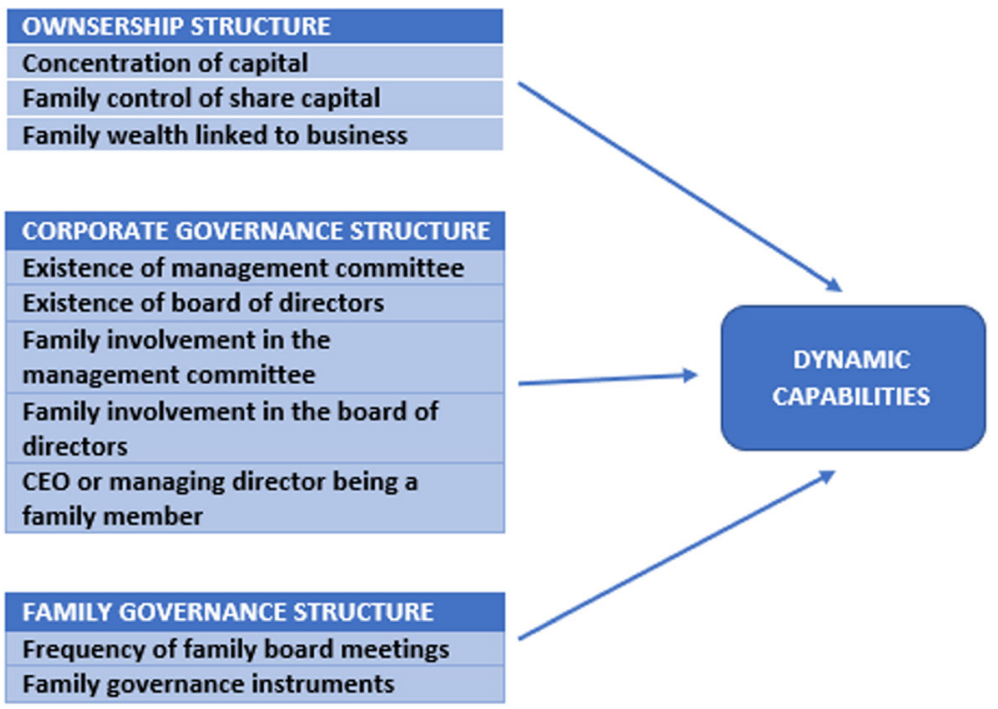

Fig. 1 The ownership and family/business governance structures as determinants of the dynamic capabilities of the FF 
decision-making, taking advantage of opportunities and risk attitudes (Williamson 1979; Fama and Jensen 1983, 1985). As has been highlighted by both agency theory (Jensen and Meckling 1976; Fama 1980; Fama and Jensen 1983; Eisenhardt 1989) and the RCBV (Teece 2007), the key element is the effect of ownership structure on risk aversion, which is the main obstacle to having a strategic vision of the need for innovation. In this regard, family control of the share capital, the degree of concentration of capital and the share capital as a proportion of the family's accumulated wealth all constitute aspects of the capital structure that are a priori potential explanatory factors in the development of dynamic capabilities.

When the family holds a high percentage of the share capital it indicates a perceived need for the owning family to maintain its control and decision-making power over the $\mathrm{FF}$, both in the present and for future generations. That is, family control is linked to the owning family's long-term commitment to the business (Voordeckers et al. 2014; European Commission 2015). Therefore, a typical objective of the owning family is to ensure firm survival. This aim is shaped by the desire of the founders and their heirs that subsequent generations should be the beneficiaries of their work and capital. The mission that the owning family sets for the FF therefore tends to be focused on firm survival and the preservation of the accumulated wealth for future generations (Churchill and Hatten 1987), rather than on the creation of value as advocated by classical financial theory (Jensen and Meckling 1976). Family control of the share capital therefore results in the use of the business as a way to protect non-economic family objectives (Chrisman et al. 2004). In this sense, the FF is often more focused on concentrating wealth in the hands of the family and preserving it for future generations (Fitz-Koch and Nordqvist 2017). As such, FFs are more oriented towards preserving wealth than creating it (Le Breton-Miller and Miller 2006; Memily et al. 2010).

The development of the dynamic capabilities needed for the FF to innovate is influenced by the degree to which the owning family has a clear understanding of the fact that firm survival in an environment of intense competition and continuous change requires technological and organizational renewal. However, the typical objective of an FF may make it difficult for the owning family to have a clear grasp of this strategic challenge (Classen et al. 2012; Nieto et al. 2015). The idea of preserving family wealth for subsequent generations and the goal of firm survival can mean that investment opportunities are turned down if there is a chance they may endanger the accumulated private profits of the controlling family (Demsetz and Lehn 1985). This attitude leads to greater conservatism in the firm's actions (Bertrand and Schoar 2006); that is, greater risk aversion (Romano et al. 2001; Croci et al. 2011; Koropp et al. 2013).

Risk aversion stemming from the desire for intergenerational survival can lead to an avoidance of investments that entail a high degree of uncertainty and which may have a damaging effect on the value of the business inheritance and family security in the event of failure (Duran et al. 2016). The need for stability can be an impediment to the development and adoption of new processes (Cucculelli et al. 2016), and can thus act as a barrier to learning new skills (Gómez-Mejia et al. 2001; Schulze et al. 2001, 2003). The preferences that the family ownership transfer to the management will thus be oriented towards: expanding in such a way that secures the incoming generations' place within the same business; implementing practices aimed at ensuring that the investments already made yield a profit; and extracting income in the form of dividends. If resources are not allocated for innovation, there is less of a need to identify and 
establish new opportunities. Similarly, it becomes less useful to engage in activities such as scanning the environment for technological opportunities, which are an essential ingredient of the sensing capability. Such priorities are sure to have an adverse impact on a firm's seizing capability in innovation. In addition, the risk-averse attitude associated with family control may act as a barrier to the introduction of innovations that diverge from the firm's traditional business approach and require new skills (Cucculelli et al. 2016), which is critical for developing transforming capabilities. Thus, when conservative behaviour becomes established in FF, it can impede the development of dynamic capabilities by reducing the perceived need for them as well as the opportunities for learning them.

The greater the family's ownership of the share capital, the more intense this negative effect of family control on dynamic capabilities, as the decision-making will increasingly be in the hands of the family (Schulze et al. 2003; Eddleston et al. 2008). On the other hand, the increased presence of external capital, from sources outside the family, limits the risk aversion of the FF (Hiebl 2015). We can thus formulate the following hypothesis:

\section{H1. There is a negative relationship between the percentage of share capital owned by the family and dynamic capabilities}

Agency theory emphasizes that risk aversion can be intensified by the influence of the ownership structure (Jensen and Meckling 1976). Risk aversion increases with a higher degree of ownership concentration (Denis et al. 1997; Schulze et al. 2003). Sensing activities, such as monitoring trends in new technologies, primarily require a long-term perspective; however, they do not require large capital investments, as they can be deployed simply by employees incorporating the search for opportunities into their daily work. Thus, the negative effects of risk aversion and problems with securing debt financing appear to be limited in relation to this dynamic capability. In contrast, seizing and transforming activities require substantial investment. These investments may be hampered by difficulties in securing capital, which stem from the financial conservatism often seen in FF with concentrated family control (Mishra and McConaughy 1999; Gómez-Mejía et al. 2007; Le Breton-Miller et al. 2011; Lichtenthaler and Muethel 2012). Shareholder resistance to debt is exacerbated by the sense of loss of control when a firm opens itself up to external capital — as the suppliers of that capital demand information and even participation in strategic decisions - and by fear of financial distress. Concentrated family control of share capital can mean that the size of investments is restricted by the amount of available internal funds and the family's wealth (Poutziouris 2001). This limited financial capacity narrows the window of opportunity for innovation projects (Mishra and McConaughy 1999; Michiels and Molly 2017). Moreover, when investment projects are focused on the development of intangible assets, such as those that support dynamic capabilities, it can reduce internal financing capacity during the protracted period required for such investments to generate positive income flows. Investments in intangibles take a long time to yield a profit. (Dierickx and Cool 1989). Dependency on debt financing may also be detrimental to investment in intangibles - such as all the assets related to knowledge and information - due to their low value as collateral (Caneghem and Campenhout 2010). This weakens the drive for investments that facilitate the development of dynamic 
capabilities. In any case, the temporary diseconomies that necessarily occur before intangible assets start to become profitable make them a more uncertain investment; a feature which does not fit well with the risk aversion associated with family control of capital (Eddleston et al. 2008).

It can thus be hypothesized that:

\section{H2. There is a negative relationship between the percentage of share capital held by the largest shareholder and dynamic capabilities}

The attitude of FF owners to risk and possible agency problems will also differ depending on the share of the family's wealth tied up in the business. The level of family wealth committed to the business - in many cases, the family's entire wealth (Anderson et al. 2003) — may also have a determining influence on the owning family's decisions regarding the desired level of risk and growth objectives (Duran et al. 2016). The increase in the family wealth committed to the company is directly linked to the longevity of the firm, and therefore to the number of generations that have had ownership of it. Given that with each successful generational change, the family wealth linked to the business in surviving FFs tends to increase, succession is accompanied by a growing risk aversion on the part of the owning family (Sharma et al. 1997; Denis et al. 1997; Schulze et al. 2002; Naldi et al. 2007; Teece 2007). This is due to the desire not to compromise family security through the possibility of failure resulting from the uncertainty inherent to risk-taking (Ward 1997; Duran et al. 2016). The security and wealth accumulated as a result of past success lead to the family becoming settled and losing its entrepreneurial spirit (Schulze et al. 2002; Gallo and Amat 2003: 77).

The processes of succession and transfer of ownership often lead to a degree of decapitalization of the FF. This can occur as a result of the need to compensate members of the new generations who do not work in the business or who disagree with its management, and even to buy out their shares to resolve conflicts. Given the problems associated with this drain on internal funds available for self-financing and the issues associated with the effect of family control on increases in equity, the positive relationship between generational change and the level of debt appears to be clearly confirmed (Molly et al. 2010; Koropp et al. 2013). This increase in the proportion of the FF's capital that is obtained through debt will only further hinder investment in the development of intangible assets such as dynamic capabilities.

The high level of family capital commitment poses a dilemma not only for increasing equity, but also when it comes to opting for diversification. When the amount of family wealth tied up in the main business reaches a substantial level, doubts may arise as to the strategic logic of concentrating all their efforts in that single business, given the risks entailed in committing a large amount of capital to a single investment. However, leaving behind the paradigms that facilitated the original entrepreneur's success and venturing into unknown terrain requires other capabilities (Cucculelli et al. 2016) that will not be developed through adherence to the historical family approach. These new capabilities, which include scanning the environment in search of opportunities (sensing) and innovation management (seizing), not to mention restructuring and rebuilding (transforming), are stifled by learning processes that rely too heavily on the value of tradition (GómezMejia et al. 2001; Schulze et al. 2001, 2003). 
We thus propose the following hypothesis:

\section{H3. There is a negative relationship between the percentage of the family wealth linked to the business and dynamic capabilities}

\section{Management and governance structures in the FF and dynamic capabilities}

The institutional overlap between the family and the business can lead to problems that manifest themselves in contradictions: what is expected of individuals from a family perspective often comes into conflict with what is expected of them according to business principles. The emergence of disparate rules and interests in the two areas requires management to integrate these differences into a cohesive common project. In addition, agency theory points to the existence of FF-specific agency costs (Bertrand and Schoar 2006; Hiebl 2015) that arise when control and greater levels of information are used to benefit family interests over those of the business, family shareholders over non-family shareholders, and the shareholders with senior management positions and lenders (Villalonga et al. 2015).

Agency theory suggests there is a need for certain governance mechanisms to mitigate the negative effects of the abovementioned agency costs (e.g., Villalonga et al. 2015; Arteaga and Menéndez-Requejo 2017) and help ensure more efficient management by improving managers' professionalization, generating and sharing knowledge, and developing dynamic capabilities. Moreover, these governance mechanisms can be used to establish rules of conduct that help manage the potential divergence between business interests and family interests, among other issues. Some of these instruments are specific to FFs; however, there are other bodies that are not specific to FFs but do have specific features within this context, and must be adapted in order to effectively fulfil their respective functions (Sánchez-Crespo Casanova et al. 2005).

Notable examples of mechanisms that are not specific to FFs are the board of directors and the management committee; along with the CEO of the firm, they make up the corporate governance structure. This structure provides the basis for decisionmaking and thus for the development of capabilities (Duran et al. 2016; Diéguez-Soto et al. 2018). The creation of a sound corporate governance structure that includes the governing bodies required to supervise and control the business endows the firm with professionalism (Songini 2006). In turn, professionalization opens up important opportunities for the FF in terms of the acquisition and accumulation of valuable resources for R\&D\&I (Miller and Le Breton-Miller 2006). As such, it fosters the development of dynamic capabilities.

Knowledge is a crucial aspect in the development of dynamic capabilities (Eisenhardt and Martin 2000; Zollo and Winter 2002; Chirico and Nordqvist 2010); dynamic capabilities enable the modification, development or creation of capabilities through the acquisition and recombination of knowledge (Teece et al. 1997; Eisenhardt and Martin 2000; Zollo and Winter 2002). In the FF, knowledge-both explicit and tacit - is generated through the education and experience acquired by family members within and outside the organization (Zahra et al. 2007; Chirico 2008). The creation and implementation of corporate governance mechanisms provides the FF with outlets other than the family forum in which to exchange knowledge and set out the common 
strategy to be pursued. The board of directors and the management committee thus become discussion forums for the exchange of knowledge, the generation of ideas and the implementation of changes.

We therefore propose the following hypotheses:

\section{H4: There is a positive relationship between the existence of a management committee and dynamic capabilities}

\section{H5: There is a positive relationship between the existence of a board of directors and dynamic capabilities}

These management and governance instruments facilitate the interaction between the family sphere and business sphere, helping family members to participate in both areas simultaneously, reinforcing the relationships of trust between them as well as with external agents (Cabrera-Suárez et al. 2001; Chirico 2008), and facilitating the generation and exchange of knowledge. To make effective use of knowledge resources, each individual member must understand the common goal and cooperate in seeking to achieve that goal (Chirico et al. 2011). A certain degree of family involvement in the board of directors and the management committee will enable the coordination of business and family objectives (Jaskiewicz and Klein 2007). This helps create a favourable environment for resource recombinations, which is another way of renewing capabilities (Sirmon and Hitt 2003).

However, a high degree of family involvement in the corporate governance structure can tilt it towards serving family interests at the expense of the company, exacerbating the bias towards risk aversion and limiting investment in the development of innovation capabilities. When the family acts for its own benefit rather than thinking of the company, the risk of asymmetric family altruism arises, reflecting the urge to secure and protect the future of the family by providing family members with compensation, benefits, and positions in the company (Schulze et al. 2002; Lubatkin et al. 2007). Asymmetric altruism can lead to problems such as the entrenchment of inefficient managers (Schulze et al. 2001, 2003). Altruism towards the family and practices that are unconcerned with managerial professionalization can jeopardize the development and value of capabilities if combined with high levels of family control over the company. This occurs because profits are distributed for the benefit of the family rather than to ensure value creation (Gómez-Mejia et al. 2001; Schulze et al. 2001, 2003).

One of the most common sources of FF-specific agency costs (Hiebl 2015) is illqualified family members holding positions in the company. The entrenchment of family members in governance positions can potentially limit the ability of the FF to attract talent or people with the required competencies to positions of leadership and control in the business (Bertrand and Schoar 2006; Le Breton-Miller et al. 2011). Among the disadvantages stemming from the lack of appropriate expertise of some family managers or board members, is the risk of reduced investment in the renewal of products and processes, and in knowledge acquisition (Zahra 2005; Le Breton-Miller et al. 2011) all of which are essential for the development of dynamic capabilities. Le Breton-Miller et al. (2011) find in their study that, as the number of family directors and family control of the voting rights increase, the tendency to invest in long-term initiatives such as R\&D declines. Conversely, the presence of non-family managers 
with no ownership rights can help recalibrate perceptions of value and risk associated with the most innovative decisions (Duran et al. 2016). The theoretical superior capacity of family-led companies to adapt to changing environments is therefore adversely affected by the growing tendency over successive generations to award key positions in the company to family members whose competency has not been tested in the market.

The FF tends to underestimate the value of a diverse management team or range of work experience; this is probably because the desire to "keep it in the family" results in a lack of external experience that prevents them from envisaging other business models. There is thus a vicious circle that is difficult to break, whereby greater attempts to keep the business within the family lead to an ever-more restricted kinship circle. This rejection of mobility poses a serious obstacle to the development of dynamic capabilities, for a number of reasons. First, because mobility is an indicator of people's resolve and creative character, which are essential qualities for innovation. Second, because the enriching interactions promoted by mobility provide the person in question with a variety of experiences, and thus a better understanding of why present practices fail and how to improve them. Third, because mobility involves the transmission of tacit knowledge that can only take place through personal contact and learning-bydoing. The optimal evolution of the FF would therefore be to reverse the negative dynamics associated with family-restricted systems. Parallels can be seen in both population genetics (where endogamy enables the reproduction of deleterious recessive genes, thus leading to a sort of biological population death) and in physics (where a closed endogenous physical system collapses into thermal or entropic death). Obviously, there are FFs that are successful leaders in their field and have developed hugely innovative projects, but these highly unlikely exceptions are the result of anomalies or random fluctuations, whose effect tends to be temporary.

Therefore, the following hypotheses can be proposed:

\section{H6: There is a negative relationship between greater family involvement in the management committee and dynamic capabilities}

\section{H7: There is a negative relationship between greater family involvement in the board of directors and dynamic capabilities}

Another feature of the corporate governance structure that may have a negative effect on the development of dynamic capabilities is the fact that the ownership and management can be combined in one person, the CEO (Kraiczy et al. 2015). The initial postulates of agency theory suggest that agency costs will be reduced precisely because of this combined function (Jensen and Meckling 1976; Fama and Jensen 1983), and there are certain advantages inherent to family-managed firms. The main advantage stems from the fact that in FFs with concentrated family control, the family CEOs often have a long-term mandate (Gómez-Mejia et al. 2001). In the search for investment opportunities, this long-term managerial horizon facilitates sensing activities; indeed, the principal requirement for such activities is patient management. During their lengthy time in office, family CEOs can establish long-term relationships with customers, suppliers and other critical stakeholders, thereby accumulating high levels of social capital (Schulze and Gedajlovic 2010), which then becomes a source of essential 
information for perceiving innovation opportunities (Gómez-Mejía et al. 2007). This enhanced absorptive capacity can help to stimulate learning processes aligned with new demands relating to the market or technology. The construction of strong interorganizational networks in order to remain alert to technological and commercial trends would enable the accumulation of superior internal capabilities to identify and generate innovation opportunities faster and more efficiently than competitors (Zellweger et al. 2012). In particular, the depth of experience gained during extended managerial mandates allows family managers to develop a profound tacit knowledge of their business, industry and community forged in their competitive environment, which in turn provides them with a unique viewpoint from which to deploy their sensing activities (Teece 2007). Transforming capabilities can also be enhanced by the longterm strategic orientation that tends to characterize family CEOs; the long mandate gives them both the experience and the incentives to invest in the company's future (Le Breton-Miller and Miller 2006).

However, the experience accumulated in the technologies and markets in which the FF has developed its business, and the concentration of the field of activity on the industries selected by the founder, can lead the family CEO to maintain the business focus on these areas of competition. As such, he/she may tend to neglect the search for opportunities stemming from new technological advances or emerging in different markets. Indeed, there is empirical evidence indicating that FFs restrict their search for ideas and knowledge to their immediate network of relationships (consumers, suppliers and competitors), while non-family firms focus on a wider network made up of universities, public R\&D\&I organizations and fair trade organizations (Basco and Calabrò 2016). In addition, the preference for the risk relating to a high concentration of financial wealth in traditional areas, rather than the potential drawbacks associated with new technologies or markets (Gómez-Mejia et al., 2010), can come to the detriment of efficiency in seizing activities (Lichtenthaler and Muethel 2012). One of the capabilities that may be most impaired as a result of this prioritization is a proactive orientation in search of new customers and new markets, both domestic and international (Wilken 1979; Ward 1997; Hall et al. 2001; Habbershon and Pistrui 2002), which may be outweighed by a more reactive, closed approach focused on traditional customers and markets. The firm's efforts to take advantage of innovation opportunities will thus be limited. The transforming capability can also be negatively affected because the dominant shareholder group's monopoly on decision-making positions discourages penetration into culturally new markets (Gómez-Mejia et al., 2010). This growth requires more diverse resources and experiences than can be found in the concentrated core of control and ownership; that is, it calls for listening to and incorporating external voices. However, this need collides with the family's rigidity when it comes to delegating decision-making power. The homogeneity of criteria that often accompanies concentrated family control is detrimental to the search for new opportunities. In addition, cultural and technological homogeneity reduces opportunities for learning new capabilities (Gómez-Mejia et al. 2001; Schulze et al. 2001, 2003).

Family ownership and family control of the firm's management and governance bodies also tends to mean that the mission and culture that permeate the inner family circle are transmitted to the firm as a whole (Cruz and Nordqvist 2012). Family monopoly of management and governance can curb entrepreneurial behaviour (Schulze et al. 2002) and discourage diversification (Cabrera-Suárez et al., 2001) by 
imposing traditions and resistance to change over the lifespan of the firm (Ward 1997; Hall et al. 2001)

The fact that the managing director and the family owner are the same person leads to what De Massis et al. (2015) refer to as personalism; that is, unrestricted authority. The risk here is that authority may be exercised in a way in which the objectives pursued are not necessarily linked to value maximization (Chrisman et al. 2012), since nepotism (Bertrand and Schoar 2006) plays a role in decision-making. The risks inherent to an FF focused more on serving the family than the business - as pointed out in the analysis of the effects of family involvement in corporate governance bodies - emerge once again in this context.

In light of these arguments, the following hypothesis is proposed:

\section{H8. There is a negative relationship between the CEO being a family member and dynamic capabilities}

\section{Family governance structures and dynamic capabilities}

The family governance structure encompasses all the FF mechanisms aimed at regulating the relationship between the family and the business. According to Neubauer and Lank (1999), its main purpose is to ensure the economic viability and legitimacy of the company. The key family governance mechanisms are the family board; the consensusbased drafting of a family protocol and rules that regulate the work of the family in the company; and policies on information, training, participation, investment, and capital (Mustakallio et al. 2002; Chrisman et al. 2007).

The family board regulates the functioning of the family and its relationships with the company, addressing both present issues and future projects. It helps to reinforce the values of the FF, enabling the articulation of shared beliefs, expectations and values, which are reflected in the family mission, the family protocol, the code of ethics and the code of conduct (Blumentritt et al. 2007). The more often it meets and the better organized it is, the more fluid and continuous the communication between its members will be.

With respect to management instruments, they are an important mechanism for FFs, complementing the family governance and becoming increasingly useful as the structure of the business becomes more complex. These instruments enable the FF value system to function more appropriately.

Although some FF characteristics may represent an obstacle to the exchange of knowledge (Zahra et al. 2007), establishing these family governance mechanisms can contribute to the creation and sharing of knowledge. FF-specific bodies facilitate communication and transparency between family members (e.g. Arteaga and Menéndez-Requejo 2017) and can therefore lead to more sharing of knowledge, relating to both the family and the business. Such a climate can support the development of sensing capabilities. In addition, these mechanisms help to regulate the type of behaviour resulting from excessive family control, such as the abovementioned issues of entrenchment or family altruism. The resulting regulation can be seen in the greater monitoring of managers and a stronger emphasis on professionalization (Arteaga and Menéndez-Requejo 2017), aimed at preventing the entrenchment of family members who are not qualified for certain positions and regulating the compensations and 
benefits provided to family members. All these effects can benefit investment in the development of seizing and transforming capabilities.

The integration and codification of family knowledge in the company can support proposals for changes in current strategies and help identify possible strengths and weaknesses in such proposals (Zollo and Winter 2002; Teece 2007). Management instruments such as the family protocol, the family board, or other rules, represent mechanisms through which members of the FF can generate, share, and clearly set out their knowledge, thereby enabling that knowledge to be codified and used to support the firm's long-term survival (Chirico 2008; Zahra et al. 2007; Barros et al. 2016). Thus, in addition to generating new knowledge, they are useful tools for sharing knowledge and transgenerational values.

Likewise, the preservation of family values and the family dynasty through the firm, and the desire for family continuity in the business, should be oriented towards ensuring the success of the business, representing a better way to foster a commitment to learning and developing capabilities (Berrone et al. 2012). The rules governing succession and the family board, among other mechanisms mentioned above, contribute to forging a long-term vision and values in the FF. They therefore represent key tools for the generation of learning and knowledge-related capabilities.

These arguments give rise to the following hypotheses:

\section{H9. There is a positive relationship between the existence of a well-organized family board that meets frequently and dynamic capabilities}

\section{$\mathrm{H} 10$. There is a positive relationship between the use of family governance tools and dynamic capabilities}

\section{Methodology}

\section{Sample design}

The final sample consists of data on a total of 748 family tourism firms obtained from the database FAMITUR. The family tourism firm in Spain, developed by the Spanish Institute of Tourism Studies. This database contains data on a sample of 1019 tourism companies. Data were collected using a questionnaire administered through personal interviews. Regarding the interviewees, it was decided that the owner, managing director or general manager of the company were the appropriate people to provide their responses to the questionnaire.

This initial sample was selected using a stratified random sampling procedure with proportional allocation to ensure the representativeness of the sample in terms of activity (four groups), size (taking the number of employees as a measure of firm size) and location.

In addition, we performed a number of statistical analyses to assess the severity of common method bias. First, the Harman one-factor test on the items indicated that this bias was not an issue. That is, multiple factors were detected, and the variance did not merely stem from the first factors (Podsakoff and Organ 1986). In fact, the independent variables included in the model form several factors with eigenvalues higher than 1 and 
the first two factors capture only 22.25 and $15.8 \%$ of the total variance, respectively. We also included control variables that have a bivariate correlation below 0.3 (Siemsen et al. 2010) between the other variables in the model.

The statistical tests do not eliminate this risk; however, they suggest that our results are not driven predominantly by common method variance. Moreover, our results are based on complex estimations that involve multiple independent variables and interaction terms. It has been argued that it is highly unlikely that the results of such models emerge solely as a result of common methods bias (Siemsen et al. 2010). To assess the severity of multicollinearity, we computed variance inflation factors (VIFs) with an average VIF value of $y$ and the maximum VIF value of 2.4, which are far below the cut-off point of 10 (Cohen et al. 2013), indicating that multicollinearity does not pose a problem to our estimation models.

As suggested by Armstrong and Overton (1977), the time trend extrapolation test was used to check for the possible existence of non-response bias. This test is based on a comparison of the first and last questionnaire respondents. The results of the t-tests show that no significant differences are observed in any of the explanatory or dependent variables. The field work was carried out between December 2009 and March 2010.

To avoid potential common source bias, 450 of the companies that had responded to the questionnaire were contacted, but in this case the interviewee was a different person from the one who completed it the first time. The aim was to obtain a new response on the scale of dynamic capabilities. The interview was arranged and conducted by telephone for 248 companies that agreed to this new process, representing a response rate of $51.1 \%$ for the second questionnaire.

\section{Analytical technique}

This study uses multiple linear regression analysis, a technique that enables an estimation of the relative importance of the different explanatory variables discussed above, in terms of their effect on dynamic capabilities. The SPSS 21.0 program for Windows has been used for the statistical analysis of the data drawn from the primary source. The estimated results are statistically robust; residual analysis as well as other graphs and statistics provided by the SPSS program have been used to ensure that the basic assumptions for linear regression analysis (linearity, independence, homoscedasticity, normality and no collinearity) are met.

\section{Measurement of the variables}

The dynamic capabilities are measured through a multi-item Likert scale, specifically a 7-point semantic differential scale with scores reflecting the managers' perception of the strength of their firm in terms of their endowment of capabilities compared to competitors in the industry (from $1=$ "much worse", to 7 = "much better"). The scale is consistent with our approach, which entails measuring innovation capabilities rather than innovation output. The validity of the content is ensured through the inclusion of items that reflect technological capabilities for innovation. The construct was organized on the basis of the three facets detailed by Teece (2007), which have also been applied in the subsequent literature on the same problem (Lichtenthaler and Muethel 2012; 
Fitz-Koch and Nordqvist 2017) (Appendix 1). Since the empirical models have been tested using regression analysis, the variable dynamic capabilities has been introduced into the model as the arithmetic mean of all the indicators. The measurement of this variable has been shown to be consistent and reliable, with a Cronbach's Alpha of 0.931 , well above the 0.7 proposed by Hair et al. (2006).

The family influence exerted through the design of and participation in the governance and management bodies lies on a continuum, ranging from absolute control of the strategic decisions to delegating them to an outside professional (Schulze and Gedajlovic 2010). As such, the measure of family involvement should preferably be a continuous rather than a categorical variable (Klein et al. 2005; Sirmon et al. 2008). However, since family involvement is disaggregated into the three abovementioned aspects (ownership, business governance and family governance) it can be measured even more accurately and objectively. The explanatory variables are measured as follows:

Concentration of capital the percentage of the share capital held by the largest shareholder.

Family control of share capital the percentage of the share capital held by the family.

Family wealth linked to the business dichotomous variable which takes a value of 1 if $60 \%$ or more of the family wealth is linked to the business; and 2 otherwise.

Existence of a management committee dichotomous variable.

Existence of a board of directors dichotomous variable.

Family involvement in the management committee percentage of family members.

Family involvement in the board of directors percentage of family members.

Managing director or CEO being a family member dichotomous variable indicating whether or not the managing director or CEO is a member of the family.

Frequency of family board meetings number of meetings of the body per year.

Family governance instruments number of existing instruments such as a family board, family protocol and rules governing work, power distribution and transfer of ownership.

The control variables introduced were size, age, subsector of activity and strategic profile. Size was measured as the number of employees, while the age of the firm was taken as the number of years since it was founded. The strategic archetypes correspond to the typology put forward by Miles et al. (1978), with three dichotomous variables that capture the defender, prospector or analyser strategy profiles, leaving the reactor profile as a reference variable. The tourism subsector to which the company belongs has also been included. These categories of tourism activity are accommodation, restaurants and 
catering, intermediary services, and transport, with the complementary tourist offer left as a reference category.

The discriminant validity between the study variables was evaluated using the correlation matrix. The levels of correlation between the variables are all below 0.6 (Churchill Jr 1979), as can be seen from the analysis in Table 1, which presents the descriptive statistics and correlations of the study variables for the sample.

\section{Results}

The estimation of the model involves a two-stage procedure, with the first estimation including the control variables (Model 1) before subsequently adding the explanatory variables (Model 2). The significance of the F-statistic for the two estimated models (Table 2) indicates acceptable explanatory power (0.218).

Table 3 presents the estimates from the two models. An initial look at the results confirms that a number of aspects have an influence on the accumulation and development of dynamic capabilities, with most of the proposed hypotheses being confirmed.

With respect to the variables related to the ownership structure, a higher percentage of family-owned share capital, a higher concentration of share capital in the hands of the largest shareholder, and a higher percentage of family wealth linked to the business, have a negative and significant effect on dynamic capabilities. This confirms hypotheses $\mathrm{H} 1, \mathrm{H} 2$ and $\mathrm{H} 3$.

With regard to the corporate governance structure, the existence of a management committee has a positive effect on the development of dynamic capabilities, as proposed in H4. Also confirmed are $\mathrm{H} 6$ and H8, which predicted that a high degree of family involvement in the management committee and the top executive being a family member would have a negative effect. Conversely, this negative effect is not observed with family involvement in the ultimate corporate governance body, the board of directors; no significant effect is found for either the existence of such a body nor the proportion of family members involved, thus contradicting the predictions of $\mathrm{H} 5$ and $\mathrm{H} 7$.

Regarding the impact of the family governance structure, more frequent family board meetings and the implementation of family management tools have a positive impact on the development of dynamic capabilities, as proposed in H9 and H10.

\section{Discussion}

The research results have interesting academic implications on literature in some areas: corporate governance, family governance and its implications for corporate governance and development of capabilities, innovation management and resources-and capabilities portfolio.

Our evidence about the effects of ownership structure supports agency theory (e.g., Williamson 1979; Fama and Jensen 1983, 1985; Jensen and Meckling 1976) regarding the importance it assigns to the ownership structure and the prevention of the negative 


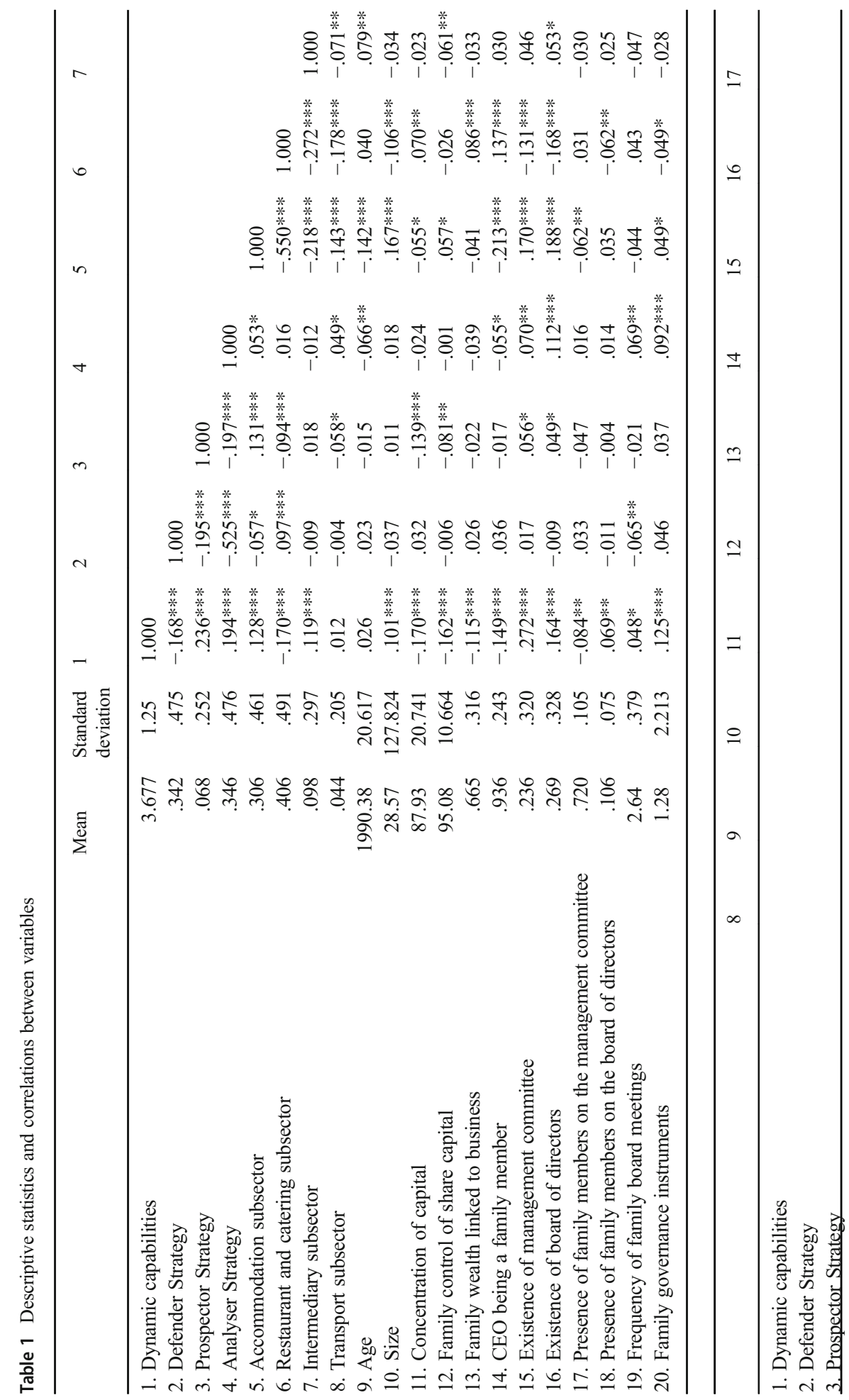




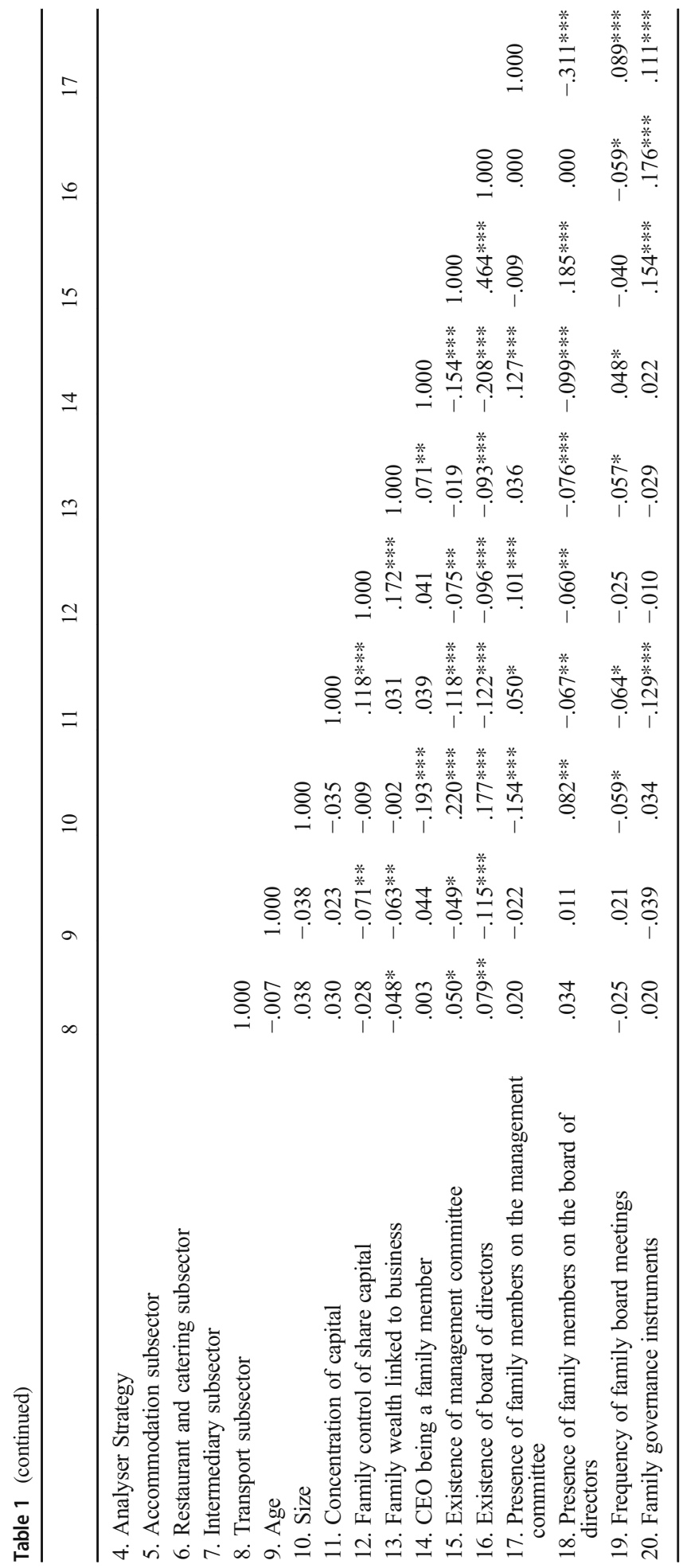


Table 2 ANOVA for the models

\begin{tabular}{llllll}
\hline Model & & Sum of squares & d.f. & Mean square & F \\
\hline 1 & Regression & 182.358 & 9 & 20.262 & 15.134 \\
& Residual & 988.079 & 738 & 1.339 & \\
Total & 1170.437 & 747 & & \\
$\mathrm{R}$ & $\mathrm{R}^{2}$ & Adjusted $\mathrm{R}^{2}$ & Standard error of the estimate \\
& .395 & .156 & .146 & 1.15709 & 11.959 \\
2 & Regression & 278.407 & 19 & 14.653 & \\
& Residual & 892.030 & 728 & 1.225 & \\
& Total & 1170.437 & 747 & & \\
& $\mathrm{R}$ & $\mathrm{R}^{2}$ & Adjusted $\mathrm{R}^{2}$ & Standard error of the estimate \\
& .488 & .238 & .218 & 1.10694 & \\
\hline
\end{tabular}

effects of the family-ownership organizational form on the exploitation of opportunities and risk-taking. In particular, while there is an open debate on how the typical FF ownership structure determines its investment policies (Gedajlovic and Carney 2010; Duran et al. 2016) our results seem to point towards a negative effect. Sensing, seizing and transforming capabilities will be adversely affected by this conservative attitude. This evidence of the negative impact on the dynamic capacities of the concentration of property and family wealth in the business, as well as of family control of capital, should force a rethinking of the theses exposed in theories such as SEW (Wiseman and Gomez-Mejia 1998; Gómez-Mejía et al. 2007). The link between family control and a greater desire for survival, defended in this approach, is contradictory with the deterioration of the capacity for innovation that constitutes the basis for the adaptation of the company over time.

Family control of capital is associated with an emphasis on firm survival rather than value creation. The consequences of this objective function for FFs is a controversial subject in the literature. The aim of firm survival is not an intrinsically negative one, to the extent that taking a long-term perspective could lead to a better understanding of the technological and organizational renewal that is essential in order to adapt to the changes that will doubtlessly arise over that extended period of time (Harris et al. 1994). The commitment to maintaining family control over the generations facilitates the decision to make investments with a long-term pay-off (Schulze and Gedajlovic 2010). The FFs who wish to thrive over time should develop a kind of "survivability capital" based on an awareness of the need to continuously transform products and processes in order to strengthen the competitive position of the firm (Sirmon and Hitt 2003). In order to achieve the goal of ensuring a "sustained family legacy", an entrepreneurial orientation must be maintained over successive generations (Chrisman et al. 2003). An emphasis on the future and the sustainability of the business secure the commitment of the FF by providing an entrepreneurial mindset (Lumpkin and Dess 1996). Moreover, intergenerational survival should make the firm predisposed towards risk-taking, enhancing management's willingness to commit high levels of resources to exploiting market opportunities (Lumpkin and Dess 1996). This represents an important advantage in terms of transforming capabilities, fueling an 
Table 3 Results of the estimated models

\begin{tabular}{|c|c|c|c|c|c|}
\hline \multirow[t]{2}{*}{ Model } & \multicolumn{2}{|c|}{$\begin{array}{l}\text { Non-standardized } \\
\text { coefficients }\end{array}$} & \multirow{2}{*}{$\begin{array}{l}\text { Standardized } \\
\text { coefficients } \\
\text { Beta }\end{array}$} & \multirow[t]{2}{*}{$\mathbf{t}$} & \multirow[t]{2}{*}{ Sig. } \\
\hline & $\mathrm{B}$ & $\begin{array}{l}\text { Standard } \\
\text { error }\end{array}$ & & & \\
\hline 1 (Constant) & -3.048 & 4.157 & & -.733 & .464 \\
\hline Defender Strategy & .120 & .114 & .045 & 1.052 & .293 \\
\hline Prospector Strategy & 1.405 & .186 & .283 & 7.565 & .000 \\
\hline Analyser Strategy & .722 & .114 & .275 & 6.327 & .000 \\
\hline Accommodation subsector & .127 & .139 & .047 & .912 & .362 \\
\hline Restaurant and catering subsector & -.229 & .132 & -.090 & -1.739 & .082 \\
\hline Intermediary subsector & .434 & .176 & .103 & 2.465 & .014 \\
\hline Transport subsector & .063 & .232 & .010 & .272 & .786 \\
\hline Age & .003 & .002 & .052 & 1.525 & .128 \\
\hline Size & .001 & .000 & .083 & 2.406 & .016 \\
\hline (Constant) & -.565 & 4.073 & & -.139 & .890 \\
\hline Defender Strategy & .019 & .111 & .007 & .171 & .864 \\
\hline Prospector Strategy & 1.171 & .181 & .236 & 6.457 & .000 \\
\hline Analyser Strategy & .579 & .112 & .220 & 5.167 & .000 \\
\hline Accommodation subsector & .027 & .136 & .010 & .202 & .840 \\
\hline Restaurant and catering subsector & -.208 & .127 & -.082 & -1.644 & .101 \\
\hline Intermediary subsector & .354 & .170 & .084 & 2.075 & .038 \\
\hline Transport subsector & -.008 & .224 & -.001 & -.034 & .973 \\
\hline Age & .003 & .002 & .044 & 1.326 & .185 \\
\hline Size & .000 & .000 & .025 & .715 & .475 \\
\hline Concentration of capital & -.004 & .002 & -.074 & -2.212 & .027 \\
\hline Family control of share capital & -.011 & .004 & -.096 & -2.857 & .004 \\
\hline Family wealth linked to business & -.229 & .132 & -.058 & -1.730 & .084 \\
\hline Existence of management committee & .809 & .150 & .207 & 5.376 & .000 \\
\hline Existence of board of directors & -.139 & .147 & -.036 & -.944 & .345 \\
\hline Family involvement in the management committee & -.221 & .132 & -.059 & -1.671 & .095 \\
\hline Family involvement in the board of directors & -.094 & .127 & -.026 & -.740 & .459 \\
\hline CEO or managing director being a family member & -.436 & .177 & -.084 & -2.458 & .014 \\
\hline Frequency of family board meetings & .192 & .110 & .058 & 1.749 & .081 \\
\hline Family governance instruments & .038 & .019 & .067 & 1.984 & .048 \\
\hline
\end{tabular}

efficient transformation of innovation processes over time. An entrepreneurial family's long-term commitment to transform and innovate within an activity has been identified as one of the factors in the strategic model that has enabled the survival of the FFs known as "the Enochians" for more than 250 years (Gallo and Amat 2003: 79).

However, when this objective of long-term survival is combined with a family culture that prioritizes the preservation of wealth, the result is a risk-averse FF 
(Gómez-Mejia et al. 2001; Romano et al. 2001; Schulze et al. 2001). The literature points to a risk-averse attitude as the main obstacle to innovation (Jensen and Meckling 1976; Fama 1980; Fama and Jensen 1983; Eisenhardt 1989; Teece 2007), in that it increases the likelihood of a firm rejecting highly uncertain investments, the potential failure of which could prove costly and damaging to the business inheritance and family security (Miller and Friesen 1978; Duran et al. 2016). Our research thus confirms that the objective function of ensuring firm survival linked to a culture dominated by the desire to preserve the accumulated wealth has negative consequences in terms of innovation capabilities, thus explaining its adverse impact on innovation, as predicted in recent literature (Bertrand and Schoar 2006; Classen et al. 2012; Nieto et al. 2015; Fitz-Koch and Nordqvist 2017). The research also confirms that a high percentage of family wealth linked to the business further increases the risk aversion of the FF; since the family's well-being is heavily reliant on the business, it may prompt the firm to turn down investments that are promising in terms of new skills development but that involve significant uncertainty.

Barring a few exceptional cases, this scenario is typical of the Spanish tourism industry, which, following the success of the projects promoted by the first generation of entrepreneurs in the 1960s and 1970s, has not yet seen an equally powerful subsequent generation. The domestic industry has thus lost ground when faced with competition from foreign firms promoting innovative practices and business models.

In FFs, the concentration of capital in the hands of the largest shareholder stems from the desire to keep the ownership among a limited number of people. The literature has argued for the theoretical benefits of the existence of large shareholders with longterm investment horizons who are concerned about the family's reputation. These benefits include lessening the incentives for management to make short-sighted investment decisions and mitigating agency problems (Anderson et al. 2003). In fact, ownership concentration, which leads to the accumulation of knowledge within a small group of executives, has been empirically shown to have a positive effect on the results; indeed, it is one of the features that Ward (2016) recognized in his study of 200 companies that were at least 60 years old and that had managed to survive for longer than the average North American FF.

However, our study contradicts the theoretical interest in this factor as a mechanism for monitoring the opportunistic behaviour of managers; our findings show that it is associated with a weakening of dynamic capabilities in the FF. The perceived need for concentrated control of capital in the FF can be explained by the conviction that the majority partners can meet the capital needs of the firm without assistance from outside the family circle; or by the mere desire to retain absolute corporate power in a limited number of hands without having to make concessions or offer explanations to outsiders. In either case, the concentration of ownership in the FF ends up being associated with risk aversion (Denis et al. 1997; Schulze et al. 2003) and therefore, as our study indicates, negatively related with dynamic capabilities.

If the reason behind restricting capital to family members is the preservation of power (Schulze et al. 2003; Eddleston et al. 2008), we can find signs of autocratic leadership that rejects a variety of perspectives and experiences, and advocates a centralization of decision-making. This is detrimental to the generation of innovation capabilities (Damanpour 1996: 699), which require work environments that foster creativity, participation and commitment. There is no conclusive empirical evidence 
that, as claimed by Harris et al. (1994) and Harris and Ogbonna (1999), FFs are less enthusiastic proponents of bureaucracy and keener on shared leadership and open, flexible organizational structures. Closing off the shareholding and corporate bodies to external investors with different knowledge and experience may be an indicator of strategically conservative behaviour (Donckels and Fröhlich 1991), which acts as an impediment to the development and adoption of new processes (Cucculelli et al. 2014) and increases resistance to change (Levinson 1987) and FF inertia (Hiebl 2015).

Our research also has relevant implications for the literature about the effects of corporate governance structure in FF about the development of dynamic capabilities. The empirical results reported are a relevant contribution about the differential competitive effects of the board of directors and top management team, as well as the family involvement in both of them, which are quite obscure in the previous literature.

Drawing inspiration from agency theory, the literature (e.g., Jensen and Meckling 1976; Williamson 1979; Fama and Jensen 1983) has centered its attention on the contractual mechanisms that enable the alignment of objectives and the formal control of ownership, and in particular on the board of directors, which has been identified as the key corporate governance body. Moreover, this dimension of governance structures has been found to be so important that family involvement in these governance bodies has even been incorporated as a key element in the concept of the FF itself (e.g., Astrachan et al. 2002). Our research indicates that the prominent role played by the corporate governance model, and especially by the board of directors (and the proportion of family members involved) are not particularly relevant in terms of enhancing the development of innovation capabilities in FF. The nominal power for setting company strategy that the board of directors legally holds does not seem to translate to business practice.

Top management team is the body that really determines the approach to resource allocation Family control of the management structure is shown to act as a brake on the accumulation of dynamic capabilities, probably because the more conservative behaviour typical of FFs (Gómez-Mejia et al. 2010; Kellermanns and Eddleston 2006) can lead to resistance to change (Ward 2016). Employing family members in management positions, even if they are not sufficiently qualified, is one of the behaviors highlighted in the FF literature as a factor that dampens the entrepreneurial spirit (Peters and Buhalis 2004). A management committee with a high proportion of family members is an obstacle to the generation of new knowledge that stimulates change and innovation. Moreover, the CEO in FF where there is a concentration of ownership in the hands of the CEO has the power to overrule board decisions, and directly negatively influence organizational processes (Westhead and Howorth 2006).

Therefore, there are notorious differences in the true implications between being a manager and being a board member for the dynamic capabilities development in FF. Boards of directors in FF, whatever the family's weight in them, they seem to be configured as organs with a nominal power that is not exercised. On the other hand, top management teams gain a higher profile in the allocation of resources for innovation than that observed in companies with more open capital structures.

Another contradiction with the previous literature on corporate governance and innovation that our research reveals is the superior value of the informal family governance mechanisms (e.g., Daily and Dollinger 1992; Tagiuri and Davis 1996; Mustakallio et al. 2002), such as the family board or family protocol, in correcting the 
conservative tendencies and risk aversion that often afflict FFs. The obsession with the formal alignment of objectives that is sure to occur with corporate governance mechanisms (e.g. Mayer and Schoorman 1992; Sundaramurthy and Lewis 2003) should therefore give way to an understanding of the processes of generating shared values committed to adapting to change and innovation, which can be promoted by the owning family through its own informal governance mechanisms.

These family governance mechanisms mitigate the negative effects of a familycontrolled ownership and corporate governance structure and contribute to greater generation and sharing of knowledge throughout the company. Given the specific features of the process of developing dynamic capabilities in FFs, determined by the high percentage of family-owned share capital and the high level of family involvement in all management and corporate governance bodies (Sirmon et al. 2008), the informal mechanisms governing the family and its relationships to the business can be defined not only as a key condition for improving performance (Suess 2014; Gersick and Feliu 2014), but also as a necessary condition for creating and sharing the knowledge that serves as the basis for innovation. The family governance mechanisms seem to outweigh the corporate governance mechanisms as a structure for adjusting to the complexity of innovation in FFs (Steier et al. 2015). The literature on these specific family governance mechanisms, which is still in its infancy (Kammerlander et al. 2015), must make progress in providing a more detailed picture of how they act to facilitate the development of the firm's capabilities.

Overall, this research has interesting academic implications for the literature on innovation management and the RCBV. Despite the distinction between innovation as output and innovation as capability previously put forward by the literature (Bontis et al. 2002; Un and Cuervo-Cazurra 2004; Kellermanns et al. 2012), most studies have continued to use innovation performance as the dependent variable, thus overlooking the importance of dynamic capabilities. Our analysis shows how these capabilities vary according to the designs of the ownership and corporate and family governance structures. It thus indicates the importance of considering these variables explicitly as determinants in any analysis aimed at explaining the implemented innovation. In addition, it underlines the interest in research focused on identifying the factors that influence the development of these highly strategic capabilities.

A good deal of empirical research has found that FFs have an innovation deficit compared to non-family firms (e.g. Ward 1997). Our study provides clear evidence that the problem of innovation in the FF stems from the negative effect that certain characteristics associated with their ownership and governance structures have on the development of dynamic capabilities. Therefore, literature must to note that the longterm survival of the FF in a competitive environment, which requires sustained innovation capability, relies more on family discussion and the intergenerational transmission and sharing of knowledge in family forums and through family governance instruments, than on the analysis and rational decision-making of the corporate governance bodies. Future research should take note of this anomaly and further explore the reasons behind the asymmetrical potential of these alternative structural design mechanisms for FFs in terms of developing dynamic capabilities.

The control variables that have a positive and significant effect on dynamic capabilities in the FF are size, the adoption of a prospector or analyser strategy, and belonging to the intermediary services subsector. Conversely, belonging to the 
restaurant and catering subsector is negatively and significantly related to the dependent variable. The intense penetration of digital business models in the former subsector, and the small firm size and low level of managerial qualifications typical in the latter, are potentially reasonable explanations for these differences in the development of dynamic capabilities.

These findings have important practical implications, as it provides guidance to owning families on how to design their FFs to prevent or correct obstacles that undermine their adaptive capacity. The existence of a management committee turns out to be a key variable for the development of dynamic capabilities in the FF. The existence of this committee seems to extend the decision-making and planning roles to a larger group of people in the company, which provides discretion, transparency and a more strategic vision when it comes to accumulating intangible skills and competencies. The management committee endows the firm with a more professional approach to management, providing a vision that does not focus solely on the family. As decision-making is more decoupled from benefits to the family, it becomes more rational, leaning towards investments in the assets, resources and capabilities needed to develop innovation. The same is true of other FF mechanisms which also enable greater standardization and objectivity of management, such as the existence of an operational family board, family protocol and other rules and instruments for family management. Therefore, all those mechanisms that endow the FF with greater rationality turn out to be positive for the development of dynamic capabilities.

Conversely, in order for the corporate governance structure to have a positive influence on the development of dynamic capabilities, FF must note it is not enough to simply implement bodies to serve this purpose. It is also necessary to prevent a high level of family involvement in these bodies, in order to avoid the potential for behaviour guided by affective ties rather than competence and economic logic. The firm's founder tends to be a strategic innovator, because he/she has no corporate history, past or traditions to maintain. But after passing on the baton, the figure of the founder and the history of the company he/she founded become pivotal points of reference for the family unit. A common error FFs make is to remain committed to honouring that tradition and resisting change. This is the prototype that Colli and Kirby (2002) refer to as the "dynastic model", whereby the firm is committed to preserving the original competitive advantage and confining leadership to the family circle. The FFs that avoid making this error adopt an "open model", which is characterized by leadership shared with employees outside the family circle, and strategy targeted at the most profitable business opportunities, regardless of whether or not they are aligned with the guidelines set out in the past by the founder.

This research has used a large sample of FFs to gather robust empirical evidence, albeit with data relating only to a single period and a single sector. Future studies should attempt a more in-depth exploration of how these variables are combined to better enhance the development of dynamic capabilities in the FF. To that end, they should use panel data and cross-industry samples. Also, future research could elaborate on the implications of a risk-averse attitude for family firms that enter into a dynamic of lesser development of dynamic capacities at the same time they seek for intergenerational succession and, therefore, the sustainability of the business over time. The RCBV perspective has precisely pointed out the dynamic capacities as the basis for the renewal of the competitive advantage and therefore the generation of new competitive 
advantages. In this sense, one future line of research should be the comparative study of the attitude to innovation of the board of directors, top management team and family councils. There is a need to better understand the actual functioning of boards in FF, what decisions they make and how they actually exercise their power to set strategic guidelines. It is also interesting to focus on how the members of this corporate body are selected and what their real motivations are. To this end, a qualitative study should be carried out to investigate, through in-depth interviews, the objectives and skills profiles of family members represented on governing and management bodies, and the extent to which they are motivated by power and economic compensation or by a real desire to contribute to the survival of the FF. Finally, a more up to date database would definitely yield more contextualized results, especially given the extraordinary impact COVID-19 will have on the tourism industry sustainability and the tourism firm business model.

\section{Conclusion}

This study examines how the distinctive features of the FF affect the generation of the firm's dynamic capabilities. Most of the previous literature has opted to analyse how FF characteristics influence performance or value creation (e.g., McConaughy et al. 2001; Chrisman et al. 2002, 2005; Villalonga and Amit 2006), without focusing on the development of its dynamic capabilities, which are underlying factors in sustainable value creation, according to the postulates of the RCBV. While there have been some contributions that examine certain FF-specific advantages and disadvantages in the accumulation of resources and capabilities (e.g., Sirmon and Hitt 2003; Sharma and Manikutty 2005; Miller and Le Breton-Miller 2006), there are virtually no empirical studies that attempt an analysis of the impact of FF characteristics on the development of dynamic capabilities. In order to analyse these characteristics, this study has focused on the main distinguishing features of FFs related to the ownership, corporate governance and family governance structures.

The main elements that discourage the development of dynamic capabilities in the FF are: (a) certain designs of ownership structure (based on the concentration of share capital in the hands of the family and the largest shareholder being a family member, and family wealth tied up in the business) that reveal the family's desire to maintain control of the firm and indicate conservative behaviour and risk aversion; and (b) management structures restricted to the family circle (based on the control of both the $\mathrm{CEO}$ and the senior management team), which block the incorporation of new highlevel knowledge that fosters the exploration of new opportunities. The most powerful positive levers that can help prevent or alleviate these negative effects are: (a) the existence of a management committee that enables the combination of different skills, experiences and knowledge to encourage creativity; and (b) the introduction of family governance mechanisms that foster open debate, which helps to overcome resistance to change and risk aversion.

\section{Appendix 1}

MEASUREMENT SCALE FOR DYNAMIC CAPABILITIES.

Sensing capability. 
The firm continually expands its portfolio of technological competencies.

The firm promotes internal knowledge development through R\&D\&I.

The firm works to identify and acquire external knowledge.

The firm continuously scans the environment to identify trends in its relevant technologies.

The firm is able to process and assimilate external knowledge and combine it with internal knowledge to usefully apply it to new applications.

Seizing capability.

The firm has the capacity to exploit and apply knowledge to the development of product innovations.

The firm has the capacity to exploit and apply knowledge to the development of process innovations.

The firm effectively integrates new technological knowledge with the existing knowledge base.

Transforming capability.

The firm continually renews its innovation management approaches and practices to improve its competitiveness.

The firm strives to improve its innovation management in order to increase its ability to adapt to changes in the environment.

The firm continuously analyses the redesign and reconfigurations of its technology management processes to optimize their alignment with changes in the environment.

The firm continuously adjusts its management of R\&D\&I to meet the needs and opportunities arising from new technologies or new markets.

\section{References}

Amit, R., \& Schoemaker, P. J. (1993). Strategic assets and organizational rent. Strategic Management Journal, 14(1), 33-46.

Anderson, R. C., Mansi, S. A., \& Reeb, D. M. (2003). Founding family ownership and the agency cost of debt. Journal of Financial Economics, 68(2), 263-285.

Armstrong, J. S., \& Overton, T. S. (1977). Estimating nonresponse bias in mail surveys. Journal of Marketing Research, 14(3), 396-402.

Arteaga, R., \& Menéndez-Requejo, S. (2017). Family constitution and business performance: Moderating factors. Family Business Review, 30(4), 320-338.

Astrachan, J. H., Klein, S. B., \& Smyrnios, K. X. (2002). The F-PEC scale of family influence: A proposal for solving the family business definition problem. Family Business Review, 15(1), 45-58.

Barney, J. (1991). Firm resources and sustained competitive advantage. Journal of Management, 17(1), 99120.

Barney, J., Wright, M., \& Ketchen Jr., D. J. (2001). The resource-based view of the firm: Ten years after 1991. Journal of Management, 27(6), 625-641.

Barros, I., Hernangómez, J., \& Martin-Cruz, N. (2016). A theoretical model of strategic management of family firms. A dynamic capabilities approach. Journal of Family Business Strategy, 7(3), 149-159.

Basco, R., \& Calabrò, A. (2016). Open innovation search strategies in family and non-family SMEs: Evidence from a natural resource-based cluster in Chile. Academia Revista Latinoamericana de Administracion, 29(3), 279-302.

Berrone, P., Cruz, C., \& Gomez-Mejia, L. R. (2012). Socioemotional wealth in family firms: Theoretical dimensions, assessment approaches, and agenda for future research. Family Business Review, 25(3), 258279.

Bertrand, M., \& Schoar, A. (2006). The role of family in family firms. Journal of Economic Perspectives, 20(2), 73-96. 
Block, J. H. (2012). R\&D investments in family and founder firms: An agency perspective. Journal of Business Venturing, 27(2), 248-265.

Blumentritt, T. P., Keyt, A. D., \& Astrachan, J. H. (2007). Creating an environment for successful nonfamily CEOs: An exploratory study of good principals. Family Business Review, 20(4), 321-335.

Bontis, N., Crossan, M. M., \& Hulland, J. (2002). Managing an organizational learning system by aligning stocks and flows. Journal of Management Studies, 39(4), 437-469.

Brown, S. L., \& Eisenhardt, K. M. (1995). Product development: Past research, present findings, and future directions. Academy of Management Review, 20(2), 343-378.

Cabrera-Suárez, K., De Saá-Pérez, P., \& García-Almeida, D. (2001). The succession process from a resourceand knowledge-based view of the family firm. Family Business Review, 14(1), 37-48.

Caneghem, T. V., \& Campenhout, G. V. (2010). Quantity and quality of information and SME financial structure. Small Business Economics, 39(2), 341-358.

Carnes, C. M., \& Ireland, R. D. (2013). Familiness and innovation: Resource bundling as the missing link. Entrepreneurship Theory and Practice, 37(6), 1399-1419.

Chirico, F. (2008). Knowledge accumulation in family firms: Evidence from four case studies. International Small Business Journal, 26(4), 433-462.

Chirico, F., \& Nordqvist, M. (2010). Dynamic capabilities and trans-generational value creation in family firms: The role of organizational culture. International Small Business Journal, 28(5), 487-504.

Chirico, F., \& Salvato, C. (2008). Knowledge integration and dynamic organizational adaptation in family firms. Family Business Review, 21(2), 169-181.

Chirico, F., Sirmon, D. G., Sciascia, S., \& Mazzola, P. (2011). Resource orchestration in family firms: Investigating how entrepreneurial orientation, generational involvement, and participative strategy affect performance. Strategic Entrepreneurship Journal, 5(4), 307-326.

Chrisman, J. J., Chua, J. H., \& Steier, L. P. (2002). The influence of national culture and family involvement on entrepreneurial perceptions and performance at the state level. Entrepreneurship Theory and Practice, 26(4), 113-130.

Chrisman, J. J., Chua, J. H., \& Steier, L. P. (2003). An introduction to theories of family business. Journal of Business Venturing, 18(4), 441-448.

Chrisman, J. J., Chua, J. H., \& Litz, R. A. (2004). Comparing the agency costs of family and non-family firms: Conceptual issues and exploratory evidence. Entrepreneurship Theory and Practice, 28(4), 335-354.

Chrisman, J. J., Chua, J. H., \& Sharma, P. (2005). Trends and directions in the development of a strategic management theory of the family firm. Entrepreneurship Theory and Practice, 29(5), 555-575.

Chrisman, J. J., Chua, J. H., Kellermanns, F. W., \& Chang, E. P. (2007). Are family managers agents or stewards? An exploratory study in privately held family firms. Journal of Business Research, 60(10), 1030-1038.

Chrisman, J. J., Chua, J. H., Pearson, A. W., \& Barnett, T. (2012). Family involvement, family influence, and family-centered non-economic goals in small firms. Entrepreneurship Theory and Practice, 36(2), 267293.

Chrisman, J. J., Chua, J. H., De Massis, A., Frattini, F., \& Wright, M. (2015). The ability and willingness paradox in family firm innovation. Journal of Product Innovation Management, 32(3), 310-318.

Churchill, N. C., \& Hatten, K. J. (1987). Non-market-based transfers of wealth and power: A research framework for family businesses. American Journal of Small Business, 11(3), 51-64.

Churchill Jr., G. A. (1979). A paradigm for developing better measures of marketing constructs. Journal of Marketing Research, 16(1), 64-73.

Classen, N., Van Gils, A., Bammens, Y., \& Carree, M. (2012). Accessing resources from innovation partners: The search breadth of family SMEs. Journal of Small Business Management, 50(2), 191-215.

Cohen, J., Cohen, P., West, S. G., \& Aiken, L. S. (2013). Applied multiple regression/correlation analysis for the behavioral sciences. Abingdon: Routledge.

Colli, A., \& Kirby, M. (Eds.). (2002). The history of family business, 1850-2000. Cambridge: Cambridge University Press.

Craig, J. B., \& Moores, K. (2006). A 10-year longitudinal investigation of strategy, systems, and environment on innovation in family firms. Family Business Review, 19(1), 1-10.

Croci, E., Doukas, J., \& Gonenc, H. (2011). Family control and financing decisions. European Financial Management, 17(5), 860-897.

Cruz, C., \& Nordqvist, M. (2012). Entrepreneurial orientation in family firms: A generational perspective. Small Business Economics, 38(1), 33-49.

Cucculelli, M., Mannarino, L., Pupo, V., \& Ricotta, F. (2014). Owner-management, firm age, and productivity in Italian family firms. Journal of Small Business Management, 52(2), 325-343. 
Cucculelli, M., Le Breton-Miller, I., \& Miller, D. (2016). Product innovation, firm renewal and family governance. Journal of Family Business Strategy, 7(2), 90-104.

Daily, C. M., \& Dollinger, M. J. (1992). An empirical examination of ownership structure in family and professionally managed firms. Family Business Review, 5(2), 117-136.

Damanpour, F. (1996). Organizational complexity and innovation: Developing and testing multiple contingency models. Management Science, 42(5), 693-716.

De Massis, A., Sharma, P., Chua, J. H., \& Chrisman, J. J. (2012). Family business studies: An annotated bibliography. Edward Elgar Publishing.

De Massis, A., Frattini, F., \& Lichtenthaler, U. (2013). Research on technological innovation in family firms: Present debates and future directions. Family Business Review, 26(1), 10-31.

De Massis, A., Frattini, F., Pizzurno, E., \& Cassia, L. (2015). Product innovation in family versus nonfamily firms: An exploratory analysis. Journal of Small Business Management, 53(1), 1-36.

De Massis, A., Kotlar, J., Frattini, F., Chrisman, J. J., \& Nordqvist, M. (2016). Family governance at work: Organizing for new product development in family SMEs. Family Business Review, 29(2), 189-213.

Decker, C., \& Günther, C. (2017). The impact of family ownership on innovation: Evidence from the German machine tool industry. Small Business Economics, 48(1), 199-212.

Demsetz, H., \& Lehn, K. (1985). The structure of corporate ownership: Causes and consequences. Journal of Political Economy, 93(6), 1155-1177.

Denis, D. J., Denis, D. K., \& Sarin, A. (1997). Agency problems, equity ownership, and corporate diversification. The Journal of Finance, 52(1), 135-160.

Diéguez-Soto, J., Garrido-Moreno, A., \& Manzaneque, M. (2018). Unravelling the link between process innovation inputs and outputs: The moderating role of family management. Journal of Family Business Strategy, 9(2), 114-127.

Dierickx, I., \& Cool, K. (1989). Asset stock accumulation and sustainability of competitive advantage. Management Science, 35(12), 1504-1511.

Donckels, R., \& Fröhlich, E. (1991). Are family businesses really different? European experiences from STRATOS. Family Business Review, 4(2), 149-160.

Drazin, R., \& Schoonhoven, C. B. (1996). Community, population, and organization effects on innovation: A multilevel perspective. Academy of Management Journal, 39(5), 1065-1083.

Duran, P., Kammerlander, N., Van Essen, M., \& Zellweger, T. (2016). Doing more with less: Innovation input and output in family firms. Academy of Management Journal, 59(4), 1224-1264.

Eddleston, K. A., Kellermanns, F. W., \& Sarathy, R. (2008). Resource configuration in family firms: Linking resources, strategic planning and technological opportunities to performance. Journal of Management Studies, 45(1), 26-50.

Eisenhardt, K. M. (1989). Agency theory: An assessment and review. Academy of Management Review, 14(1), 57-74.

Eisenhardt, K. M., \& Martin, J. A. (2000). Dynamic capabilities: What are they? Strategic Management Journal, 21(10-11), 1105-1121.

European Commission (2015). Promoting entrepreneurship: Family business-Main challenges faced by family firms. Retrieved from https://ec.europa.eu/growth/smes/promoting-entrepreneurship/we-work-for/familybusiness en.

Fama, E. F. (1980). Agency problems and the theory of the firm. Journal of Political Economy, 88(2), 288307.

Fama, E. F., \& Jensen, M. C. (1983). Separation of ownership and control. The Journal of Law and Economics, 26(2), 301-325.

Fama, E. F., \& Jensen, M. C. (1985). Organizational forms and investment decisions. Journal of Financial Economics, 14(1), 101-119.

Fitz-Koch, S., \& Nordqvist, M. (2017). The reciprocal relationship of innovation capabilities and socioemotional wealth in a family firm. Journal of Small Business Management, 55(4), 547-570.

Fuetsch, E., \& Suess-Reyes, J. (2017). Research on innovation in family businesses: Are we building an ivory tower? Journal of Family Business Management, 7(1), 44-92.

Gallo, M. A., \& Amat, J. M. (2003). Los secretos de las empresas familiares centenarias. Barcelona: Deusto.

Gallo, M. A., Tàpies, J., \& Cappuyns, K. (2004). Comparison of family and nonfamily business: Financial logic and personal preferences. Family Business Review, 17(4), 303-318.

Garg, V. K., Walters, B. A., \& Priem, R. L. (2003). Chief executive scanning emphases, environmental dynamism, and manufacturing firm performance. Strategic Management Journal, 24(8), 725-744.

Gedajlovic, E., \& Carney, M. (2010). Markets, hierarchies, and families: Toward a transaction cost theory of the family firm. Entrepreneurship Theory and Practice, 34(6), 1145-1172. 
Gersick, K. E., \& Feliu, N. (2014). Governing the family enterprise: Practices, performance, and research. The SAGE Handbook of Family Business, 196-225.

Gómez-Mejia, L. R., Núnez-Nickel, M., \& Gutierrez, I. (2001). The role of family ties in agency contracts. Academy of Management Journal, 44(1), 81-95.

Gómez-Mejía, L. R., Haynes, K. T., Núñez-Nickel, M., Jacobson, K. J., \& Moyano-Fuentes, J. (2007). Socioemotional wealth and business risks in family-controlled firms: Evidence from Spanish olive oil mills. Administrative Science Quarterly, 52(1), 106-137.

Gómez-Mejia, L. R., Makri, M., \& Kintana, M. L. (2010). Diversification decisions in family-controlled firms. Journal of Management Studies, 47(2), 223-252.

Habbershon, T. G., \& Pistrui, J. (2002). Enterprising families domain: Family-influenced ownership groups in pursuit of transgenerational wealth. Family Business Review, 15(3), 223-237.

Habbershon, T. G., \& Williams, M. L. (1999). A resource-based framework for assessing the strategic advantages of family firms. Family Business Review, 12(1), 1-25.

Hair, J. F., Black, W. C., Babin, B. J., Anderson, R. E., \& Tatham, R. L. (2006). Multivariate Data Analysis (6th ed.). New Jersey: Pearson Prentice Hall.

Hall, A., Melin, L., \& Nordqvist, M. (2001). Entrepreneurship as radical change in the family business: Exploring the role of cultural patterns. Family Business Review, 14(3), 193-208.

Harris, C., \& Ogbonna, E. (1999). The strategic legacy of company founders. Long Range Planning, 32(3), 333-343.

Harris, R., Martínez, J., \& Ward, J. L. (1994). Is strategy different for the family-owned business? Family Business Review, 7(2), 159-174.

Hauck, J., \& Prügl, R. (2015). Innovation activities during intra-family leadership succession in family firms: An empirical study from a socioemotional wealth perspective. Journal of Family Business Strategy, 6(2), $104-118$.

Heeley, M. B., Matusik, S. F., \& Jain, N. (2007). Innovation, appropriability, and the underpricing of initial public offerings. Academy of Management Journal, 50(1), 209-225.

Hiebl, M. R. (2015). Family involvement and organizational ambidexterity in later-generation family businesses: A framework for further investigation. Management Decision, 53(5), 1061-1082.

Jaskiewicz, P., \& Klein, S. (2007). The impact of goal alignment on board composition and board size in family businesses. Journal of Business Research, 60(10), 1080-1089.

Jensen, M. C., \& Meckling, W. H. (1976). Theory of the firm: Managerial behavior, agency costs and ownership structure. Journal of Financial Economics, 3(4), 305-360.

Judge, W. (2012). Owner type as emerging area of governance research. Corporate Governance: An International Review, 20(3), 231-232.

Kammerlander, N., \& Ganter, M. (2015). An attention-based view of family firm adaptation to discontinuous technological change: Exploring the role of family CEOs' noneconomic goals. Journal of Product Innovation Management, 32(3), 361-383.

Kammerlander, N., Dessi, C., Bird, M., Floris, M., \& Murru, A. (2015). The impact of shared stories on family firm innovation: A multicase study. Family Business Review, 28(4), 332-354.

Kellermanns, F. W., \& Eddleston, K. A. (2006). Corporate entrepreneurship in family firms: A family perspective. Entrepreneurship Theory and Practice, 30(6), 809-830.

Kellermanns, F. W., Eddleston, K. A., Sarathy, R., \& Murphy, F. (2012). Innovativeness in family firms: A family influence perspective. Small Business Economics, 38(1), 85-101.

Klein, S. B., Astrachan, J. H., \& Smyrnios, K. X. (2005). The F-PEC scale of family influence: Construction, validation, and further implication for theory. Entrepreneurship Theory and Practice, 29(3), 321-339.

Koropp, C., Grichnik, D., \& Gygax, A. F. (2013). Succession financing in family firms. Small Business Economics, 41(2), 315-334.

Kotlar, J., \& De Massis, A. (2013). Goal setting in family firms: Goal diversity, social interactions, and collective commitment to family-centered goals. Entrepreneurship Theory and Practice, 37(6), 12631288.

Kraiczy, N. D., Hack, A., \& Kellermanns, F. W. (2015). What makes a family firm innovative? CEO risktaking propensity and the organizational context of family firms. Journal of Product Innovation Management, 32(3), 334-348.

Lawson, B., \& Samson, D. (2001). Developing innovation capability in organisations: A dynamic capabilities approach. International Journal of Innovation Management, 5(3), 377-400.

Le Breton-Miller, I., \& Miller, D. (2006). Why do some family businesses out-compete? Governance, longterm orientations, and sustainable capability. Entrepreneurship Theory and Practice, 30(6), 731-746. 
Le Breton-Miller, I., Miller, D., \& Lester, R. H. (2011). Stewardship or agency? A social embeddedness reconciliation of conduct and performance in public family businesses. Organization Science, 22(3), 704 721.

Levinson, R. E. (1987). Problems in managing a family-owned business. In C. E. Aronoff \& J. L. Ward (Eds.), Family business sourcebook (pp. 169-174). Detroit: Omnigraphics, Inc..

Lichtenthaler, U., \& Muethel, M. (2012). Retracted: The impact of family involvement on dynamic innovation capabilities: Evidence from German manufacturing firms. Entrepreneurship Theory and Practice, 36(6), 1235-1253.

Lubatkin, M. H., Durand, R., \& Ling, Y. (2007). The missing lens in family firm governance theory: A selfother typology of parental altruism. Journal of Business Research, 60(10), 1022-1029.

Lumpkin, G. T., \& Dess, G. G. (1996). Clarifying the entrepreneurial orientation construct and linking it to performance. Academy of Management Review, 21(1), 135-172.

Marsh, S. J., \& Stock, G. N. (2006). Creating dynamic capability: The role of intertemporal integration, knowledge retention, and interpretation. Journal of Product Innovation Management, 23(5), 422-436.

Matzler, K., Veider, V., Hautz, J., \& Stadler, C. (2015). The impact of family ownership, management, and governance on innovation. Journal of Product Innovation Management, 32(3), 319-333.

Mayer, R. C., \& Schoorman, F. D. (1992). Predicting participation and production outcomes through a twodimensional model of organizational commitment. Academy of Management Journal, 35(3), 671-684.

McConaughy, D. L., Matthews, C. H., \& Fialko, A. S. (2001). Founding family controlled firms: Performance, risk, and value. Journal of Small Business Management, 39(1), 31-49.

Memily, E., Eddleston, K. A., Zellweger, T. M., Kellermanns, F. W., \& Barnett, T. (2010). The importance of looking toward the future and building on the past: Entrepreneurial risk taking and image in family firms. In J. A. Katz, T. Lumpkin, \& A. Stewart (Eds.), Entrepreneurship and Family Business (Vol. 12, pp. 329). Emerald Group Publishing.

Michiels, A., \& Molly, V. (2017). Financial decisions in family businesses: A review and suggestions for developing the field. Family Business Review, 30(4), 369-399.

Miles, R. E., Snow, C. C., Meyer, A. D., \& Coleman Jr., H. J. (1978). Organizational strategy, structure, and process. Academy of Management Review, 3(3), 546-562.

Miller, D., \& Friesen, P. H. (1978). Archetypes of strategy formulation. Management Science, 24(9), 921-933.

Miller, D., \& Le Breton-Miller, I. (2005). Management insights from great and struggling family businesses. Long Range Planning, 38(6), 517-530.

Miller, D., \& Le Breton-Miller, I. (2006). Family governance and firm performance: Agency, stewardship, and capabilities. Family Business Review, 19(1), 73-87.

Miller, D., Le Breton-Miller, I., Lester, R. H., \& Cannella Jr., A. A. (2007). Are family firms really superior performers? Journal of Corporate Finance, 13(5), 829-858.

Miller, D., Le Breton-Miller, I., \& Scholnick, B. (2008). Stewardship vs. stagnation: An empirical comparison of small family and non-family businesses. Journal of Management Studies, 45(1), 51-78.

Mishra, C. S., \& McConaughy, D. L. (1999). Founding family control and capital structure: The risk of loss of control and the aversion to debt. Entrepreneurship Theory and Practice, 23(4), 53-64.

Molly, V., Laveren, E., \& Deloof, M. (2010). Family business succession and its impact on financial structure and performance. Family Business Review, 23(2), 131-147.

Mustakallio, M., Autio, E., \& Zahra, S. A. (2002). Relational and contractual governance in family firms: Effects on strategic decision making. Family Business Review, 15(3), 205-222.

Naldi, L., Nordqvist, M., Sjöberg, K., \& Wiklund, J. (2007). Entrepreneurial orientation, risk taking, and performance in family firms. Family Business Review, 20(1), 33-47.

Neubauer, F., \& Lank, A. G. (1999). The family business-its governance for sustainability. Corporate Governance, 7, 114-114.

Nieto, M. J., Santamaria, L., \& Fernandez, Z. (2015). Understanding the innovation behavior of family firms. Journal of Small Business Management, 53(2), 382-399.

Nordqvist, M., \& Melin, L. (2010). Entrepreneurial families and family firms. Entrepreneurship \& Regional Development, 22(3-4), 211-239.

Nordqvist, M., Sharma, P., \& Chirico, F. (2014). Family firm heterogeneity and governance: A configuration approach. Journal of Small Business Management, 52(2), 192-209.

Peteraf, M. A. (1993). The cornerstones of competitive advantage: A resource-based view. Strategic Management Journal, 14(3), 179-191.

Peters, M., \& Buhalis, D. (2004). Family hotel businesses: Strategic planning and the need for education and training. Education+ Training, 46(8/9), 406-415.

Podsakoff, P. M., \& Organ, D. W. (1986). Self-reports in organizational research: Problems and prospects. Journal of management, 12(4), 531-544. 
Poutziouris, P. (2001). The views of family companies on venture capital: Empirical evidence from the UK small to medium-size enterprising economy. Family Business Review, 14(3), 277-291.

Randerson, K., Bettinelli, C., Fayolle, A., \& Anderson, A. (2015). Family entrepreneurship as a field of research: Exploring its contours and contents. Journal of Family Business Strategy, 6(3), 143-154.

Romano, C., Tanewski, G., \& Smyrnios, K. (2001). Capital structure decision making: A model for family business. Journal of Business Venturing, 16(3), 285-310.

Salvato, C., \& Melin, L. (2008). Creating value across generations in family-controlled businesses: The role of family social capital. Family Business Review, 21(3), 259-276.

Sánchez-Crespo Casanova, A. J., Bellever, A., Sánchez, Y., \& Sánchez, A. M. (2005). La empresa familiar: manual para empresarios: claves legales para su correcta organización y su continuidad. Deusto: Barcelona.

Schulze, W. S., \& Gedajlovic, E. R. (2010). Whither family business? Journal of Management Studies, 47(2), 191-204.

Schulze, W. S., Lubatkin, M. H., Dino, R. N., \& Buchholtz, A. K. (2001). Agency relationships in family firms: Theory and evidence. Organization Science, 12(2), 99-116.

Schulze, W. S., Lubatkin, M. H., \& Dino, R. N. (2002). Altruism, agency, and the competitiveness of family firms. Managerial and Decision Economics, 23(4-5), 247-259.

Schulze, W. S., Lubatkin, M. H., \& Dino, R. N. (2003). Toward a theory of agency and altruism in family firms. Journal of Business Venturing, 18(4), 473-490.

Sciascia, S., Mazzola, P., \& Kellermanns, F. W. (2014). Family management and profitability in private family-owned firms: Introducing generational stage and the socioemotional wealth perspective. Journal of Family Business Strategy, 5(2), 131-137.

Sharma, P., \& Manikutty, S. (2005). Strategic divestments in family firms: Role of family structure and community culture. Entrepreneurship Theory and Practice, 29(3), 293-311.

Sharma, P., Chrisman, J. J., \& Chua, J. H. (1997). Strategic management of the family business: Past research and future challenges. Family Business Review, 10(1), 1-35.

Siemsen, E., Roth, A., \& Oliveira, P. (2010). Common method bias in regression models with linear, quadratic, and interaction effects. Organizational research methods, 13(3), 456-476.

Sirmon, D. G., \& Hitt, M. A. (2003). Managing resources: Linking unique resources, management, and wealth creation in family firms. Entrepreneurship Theory and Practice, 27(4), 339-358.

Sirmon, D. G., Hitt, M. A., \& Ireland, R. D. (2007). Managing firm resources in dynamic environments to create value: Looking inside the black box. Academy of Management Review, 32(1), 273-292.

Sirmon, D. G., Arregle, J. L., Hitt, M. A., \& Webb, J. W. (2008). The role of family influence in firms' strategic responses to threat of imitation. Entrepreneurship Theory and Practice, 32(6), 979-998.

Songini, L. (2006). 15 The professionalization of family firms: theory and practice. In P. Zata, K. X. Smyrnios, \& S. B. Klein (Eds.), Handbook of Research on Family Business (pp. 269-297).

Steier, L. P., Chrisman, J. J., \& Chua, J. H. (2015). Governance challenges in family businesses and business families. Entrepreneurship Theory and Practice, 39(6), 1265-1280.

Suess, J. (2014). Family governance-literature review and the development of a conceptual model. Journal of Family Business Strategy, 5(2), 138-155.

Sundaramurthy, C., \& Lewis, M. (2003). Control and collaboration: Paradoxes of governance. Academy of Management Review, 28(3), 397-415.

Tagiuri, R., \& Davis, J. (1996). Bivalent attributes of the family firm. Family Business Review, 9(2), 199-208.

Teece, D. J. (2007). Explicating dynamic capabilities: The nature and microfoundations of (sustainable) enterprise performance. Strategic Management Journal, 28(13), 1319-1350.

Teece, D. J., Pisano, G., \& Shuen, A. (1997). Dynamic capabilities and strategic management. Strategic Management Journal, 18(7), 509-533.

Un, C. A., \& Cuervo-Cazurra, A. (2004). Strategies for knowledge creation in firms. British Journal of Management, 15(S1), S27-S41.

Villalonga, B., \& Amit, R. (2006). How do family ownership, control and management affect firm value? Journal of Financial Economics, 80(2), 385-417.

Villalonga, B., Amit, R., Trujillo, M. A., \& Guzmán, A. (2015). Governance of family firms. Annual Review of Financial Economics, 7, 635-654.

Voordeckers, W., Le Breton-Miller, I. Miller, D. (2014). In search of the best of both worlds: Crafting a finance paper for the Family Business Review. Family Business Review, 27(4), 281-286.

Ward, J. L. (1997). Growing the family business: Special challenges and best practices. Family Business Review, 10(4), 323-337.

Ward, J. (2016). Keeping the family business healthy: How to plan for continuing growth, profitability, and family leadership. Springer. 
Westhead, P., \& Cowling, M. (1998). Family firm research: The need for a methodological rethink. Entrepreneurship Theory and Practice, 23(1), 31-56.

Westhead, P., \& Howorth, C. (2006). Ownership and management issues associated with family firm performance and company objectives. Family Business Review, 19(4), 301-316.

Wilken, P. H. (1979). Entrepreneurship: A comparative and historical study. Norwood, NJ: Ablex.

Williamson, O. E. (1979). Transaction-cost economics: The governance of contractual relations. The Journal of Law and Economics, 22(2), 233-261.

Winter, S. G. (2003). Understanding dynamic capabilities. Strategic Management Journal, 24(10), 991-995.

Wiseman, R. M., \& Gomez-Mejia, L. R. (1998). A behavioral agency model of managerial risk taking. Academy of Management Review, 23(1), 133-153.

Zahra, S. A. (2005). Entrepreneurial risk taking in family firms. Family Business Review, 18(1), $23-40$.

Zahra, S. A., Sapienza, H. J., \& Davidsson, P. (2006). Entrepreneurship and dynamic capabilities: A review, model and research agenda. Journal of Management Studies, 43(4), 917-955.

Zahra, S. A., Neubaum, D. O., \& Larrañeta, B. (2007). Knowledge sharing and technological capabilities: The moderating role of family involvement. Journal of Business Research, 60(10), 1070-1079.

Zellweger, T. M., Kellermanns, F. W., Chrisman, J. J., \& Chua, J. H. (2012). Family control and family firm valuation by family CEOs: The importance of intentions for transgenerational control. Organization Science, 23(3), 851-868.

Zollo, M., \& Winter, S. G. (2002). Deliberate learning and the evolution of dynamic capabilities. Organization Science, 13(3), 339-351.

Publisher's note Springer Nature remains neutral with regard to jurisdictional claims in published maps and institutional affiliations. 